\title{
The impact of exchange rate volatility on manufacturing sector in sub-Saharan Africa (1980-2015)
}

\author{
Taiwo Akinlo \\ Adeyemi College of Education, Ondo, Nigeria \\ e-mail correspondence: taiwoakinlo@yahoo.com
}

\begin{abstract}
This study examined the impact of exchange rate volatility on manufacturing sectors in selected sub-Saharan Africa from the period 1980 to 2015. Panel data regression analysis was adopted in the study. Panel pooled OLS, panel fixed effect and Dynamic Generalised Method of Moment models were used for the estimation. The pooled OLS result shows that Gross Domestic Products and physical capital have positive impact on economic growth in sub-Saharan Africa while trade openness, interest rates and exchange rate volatility have negative impact on manufacturing sector. The results from fixed effect and Dynamic Method of moment model shows that trade openness, interest rate and exchange rate volatility have negative impact on manufacturing sector.
\end{abstract}

Keywords: exchange rate, volatility, sub-Saharan Africa, panel data, GMM, manufacturing

JEL classification: F32, F01, C82, C32

\section{INTRODUCTION}

The relationship between exchange rate volatility and manufacturing sector in sub-Saharan Africa has been a major concern of policy makers in recent time due to the impact of exchange rate volatility on any country that engaged in international trade. This relationship has also become a subject of debate in the literature. This relationship is very important in sub-Saharan Africa as this crucial time when governments of subSaharan Africa countries are worry about poor performance of manufacturing sector and the current high level of importation of manufactured goods into sub-Saharan Africa countries. The manufacturing sector in sub-Saharan Africa has been on decline comparing to other regions of the world as it plagued by various factors ranges from poor electricity supply, imported raw materials, poor demand for products and lowquality product. Oladipupo and Onotaniyohuwo (2011) stated that exchange rate volatility has a major impact on economic variables. The exchange rate volatility has an impact on cost of imported raw materials of manufacturing industries and it also has great impact on the prices of the manufacturing products. Since the introduction of Structural Adjustment Programme in 1986 in some sub-African countries the exchange rate volatility has become a major issue which the various governments have been trying to address. Several exchange rate policies have been put in place to curb the fluctuation but according to Opaoluwa, Umeh and Ameh (2010) only little achievement has been made in stabilizing the rate of exchange. The role of manufacturing sector in stimulating and transforming modern economy cannot be overemphasised. According to Fakiyesi (2005) the manufacturing sector is a dominant sector in many respects in advanced countries. It creates an avenue for increasing productivity in relation to import 
substitution and export expansion, providing foreign exchange earning capacity, increasing employment, promoting the growth of investment in the economy more than other sectors and efficiently linking different sectors together. But the achievement of these opportunities can be greatly influenced by the exchange rate volatility. This study intends to examine the relationship between manufacturing sector and exchange rate volatility sub-Saharan Africa in other to contribute to the existing literature and as evidence has shown in the existing literatures focused on the single country.

According to UNIDO (2016) manufacturing is a major force that drives the economic growth of major countries around the world through its higher productivity and innovations. In many countries manufacturing has contributed to the reduction of unemployment, poverty and source of income the governments of nations Among developing regions of the world sub-Saharan African is lagged behind in all measures of economic development such as industrialisation, per capital income, agriculture and economic growth. The manufacturing industry in sub-Saharan Africa is operating at average level and at low level of development UNIDO (2004). This can be shown through manufacturing value added as a percentage of GDP in selected sub-Saharan Africa countries in 2015 shown in Figure 1.

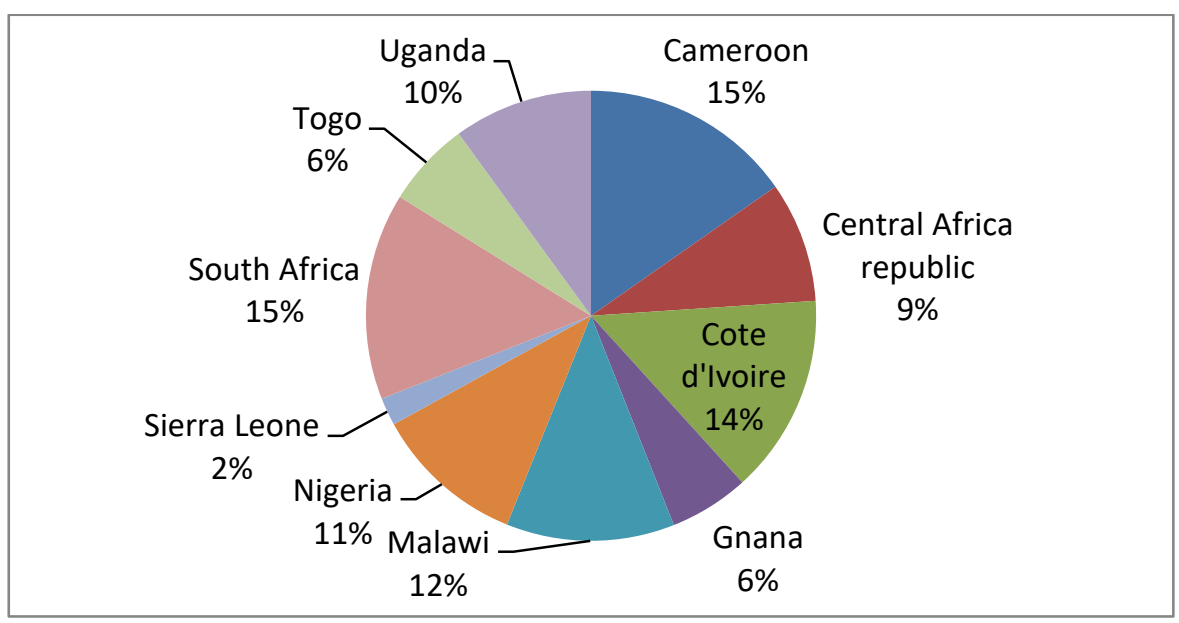

Figure 1. Manufacturing as a percentage of GDP in sub-Saharan Africa

Source: Authors computation based on data from World Bank Development Indicator.

It shows clearly from figure 1 that the percentage contribution of manufacturing sector to the GDP is very low in sub-Saharan Africa. In 2015, manufacturing form only 16 per cent of the total GDP in South Africa and Cameroon which is the highest among the selected countries in sub-Saharan Africa. In Sierra Leone it forms only 2 per cent of the total GDP and 6 per cent of GDP in Togo.

By comparing manufacturing sector in sub-Saharan Africa with other regions of the world, figure 2 shows the trend of manufacturing as a percentage of GDP from 1991 to 2013. From figure 2, it is evident that manufacturing sector in sub-Saharan is the least among the regions of the world. This figure shows that manufacturing sector is doing very well in other regions compare to sub-Saharan Africa region. For example, in East Asia and Pacific region manufacturing sector is doing well though is growing below the level of 1980's. From figure 2 the manufacturing sector was at the peak in early 90's in all the regions. The sharp decline in the manufacturing sector during the period of 2007-2010 might be due to the economic meltdown experienced across the world during that period. 


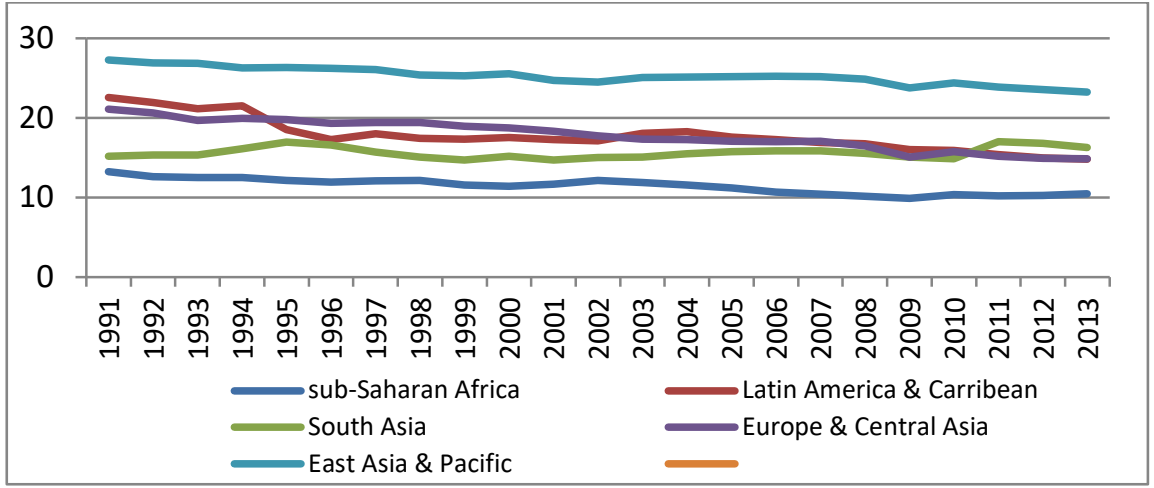

Figure 2: Trend of manufacturing sector among the regions

Source: Authors computation based on data from World Bank Development Indicator.

Figure 3 shows the regional share of value added among the regions of the world. The manufacturing value added consist of 29 per cent of the GDP in East Asia \& pacific in the year 2000. While in the same year it forms only 13 per cent of the GDP in sub-Saharan Africa. In Europe and Central Asia the manufacturing value added forms 21 per cent of the total GDP and 17 per cent of the GDP in North America. In the year 2006 the manufacturing value added as a percentage of GDP increased by 1 per cent in East Asia and pacific and Latin America and Caribbean regions. In sub-Saharan Africa it remains the same with that of 2000. But in North America and Europe and Central Asia it reduced by 1 per cent. There are little changes in 2010 as there is increase in manufacturing value added only in one region i.e East Asia \& pacific and there is decrease by 1 per cent Latin America and Caribbean. In other regions the percentages remain the same. In 2012 there is no changed in the per cent in all the regions. It is therefore evident that since 2000 there is significant improvement in the manufacturing value added products in sub-Saharan Africa.
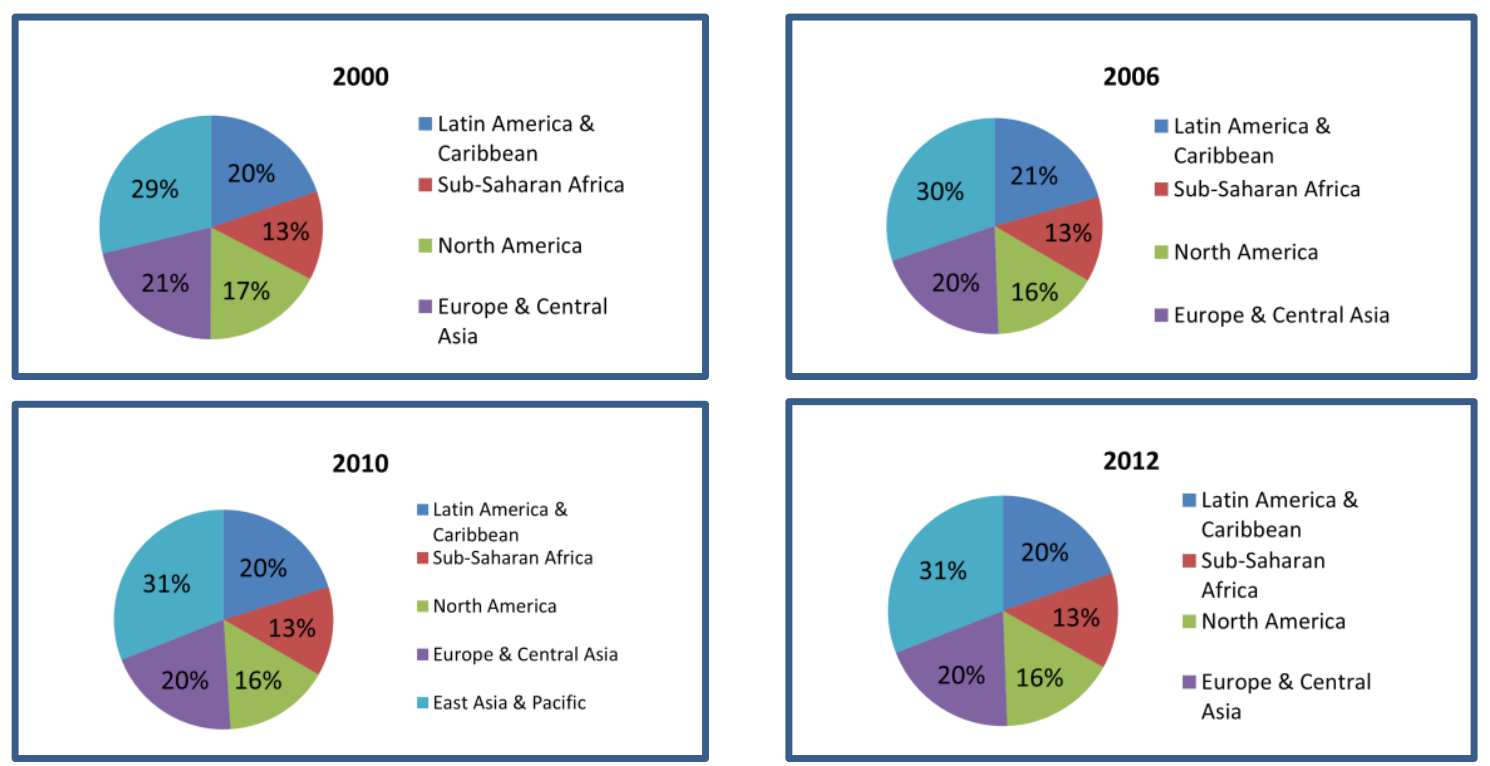

Figure 3. Regional manufacturing value added as \% GDP in 2000, 2006, 2010 and 2012.

Source: Authors computation based on data from World Bank Development Indicator.

Table 1. shows the growth rate of manufacturing sector of sub-Saharan Africa region and other regions of the world. In 2003 the rate of growth of manufacturing sector in sub-Saharan Africa is least among all the regions. The sub-Saharan Africa 
growth rate is 0.9 while the rate of growth of Europe \& Central Asia region is 4.2 which is the highest. Latin America and Caribbean and North America have the same growth rate in 2003. In 2005 there was a significant improvement in the manufacturing growth rate in sub-Saharan Africa. The growth rate of manufacturing sector is 6.3 and is the highest among all the regions. In 2010 the growth rate reduced to 6.0 and third among the regions but in 2013 the sub-Saharan Africa has the highest growth.

Table 1. Growth rate of manufacturing sector by regions

\begin{tabular}{lcccc}
\hline Region & 2003 & 2005 & 2010 & 2013 \\
\hline Sub-Saharan Africa & 0.9 & 6.3 & 6.0 & 7.9 \\
Latin America \& Carribean & 2.2 & 3.4 & 7.0 & 2.1 \\
North America & 2.2 & 2.2 & 5.3 & 1.4 \\
Europe \& Central Asia & 2.4 & 2.4 & 9.2 & 0.5 \\
\hline
\end{tabular}

Source: Authors computation based on data from World Bank Development Indicator.

Omojimite and Akpokodje (2010) examined how exchange rate volatility impacted the exports of Communaute Financiere Africaine (CFA) and non-CFA countries during the period of 1986-2006. The authors used GARCH model to generate exchange rate volatility series. Hereafter, the series generated were incorporated into an export equation and regressions were carried out using various estimations techniques including OLS, fixed effect, first difference GMM and systems GMM. The authors stated that the system GMM technique performed better than the other estimation techniques. The results indicated that exchange rate volatility negatively impacted exports of both panels of countries. However, the impact of exchange rate volatility on the panel of the non-CFA countries is greater than the CFA countries. The study recommended the need for appropriate monetary and fiscal policy actions to stem the rising exchange rate volatility.

Olayungbo, Yinusa and Akinlo (2011) focused their study on 40 selected subSaharan African countries to investigated the impact of exchange rate volatility on trade. The period of the study was between 1986-2005. This study adopted a gravity model with pooled ordinary least square (POLS) which allowing for fixed effect and panel Generalized Method of Moments (GMM) techniques. A positive impact of net effect of exchange rate volatility was found on aggregate trade in the two approaches used. The study also showed that impact of exchange rate volatility on primary and manufactured trade are very similar and also the results of ECOWAS and nonECOWAS countries. The study concluded that caution must be exercised while interpreting the results as the history of exchange rate volatility is still relatively young compared with the developed countries.

Danmola (2013) analysed the impact of exchange rate volatility on Macroeconomic variables and the study made use of Ordinary Least Square (OLS) and Granger Causality test. The results of the study showed that exchange rate volatility is positively impacted Gross Domestic Product, Foreign Direct Investment and Trade Openness, but with negative influence on the inflationary rate in the country. The author suggested the need for the country to improve in revenue base in term of increasing number of items meant for export and reduce the dependency on petroleum sector and also lower the importation of non-essential items, in order to improve their term of trade. They further suggested that effort must be made to increase in domestic production as this will minimised the impact of exchange rate volatility.

Sani, Hassan and Azam (2016) critically investigated the effect of exchange rate volatility on the output level of the five English speaking countries in ECOWAS. These 
countries include Nigeria, Ghana, Gambia, the Sierra Leones and Liberia, over the period 1991 to 2014. The study used Co-integration test and Error Correction Modelling as the estimation techniques to examine both the short-run and long-run dynamic relationships between the variables for each country. The findings from the results showed that exchange rate volatility has a significant positive impact on output of all the countries considered in the study apart from Liberia where a negative relationship was reported.

Abdul-Mumuni (2016) examined the effect of exchange rate variability on manufacturing sector performance in Ghana. This study made use of time series data covering the period of 1986 to 2013. The study adopted autoregressive distributed lag (ARDL) approach for estimation. The results from the study show that both short and long run relationship exist between exchange rate and manufacturing sector performance. The author stated that in Ghana when the exchange rate appreciates, the manufacturing sector performance improves and as it depreciates, the sector is adversely affected. As a result of this, the author recommended that appropriate policy must be put in place to regulate the importation of goods that could be locally produced so as to improve the performance of the manufacturing sector. Constant electricity supply, good roads, water and a reliable telecommunication system were also recommended to make available by the government for the manufacturing sector so that they can perform effectively and efficiently in order to achieve a considerable rate of economic growth.

Omotola (2016) focused on examining the relationship between exchange rate fluctuations and manufacturing sector output. The study focused on Nigerian economy and span through the period of 1986 to 2014. The study used Autoregressive Distribution Lag (ARDL) technique of estimation to examine the relationship. As the results indicated, exchange rate fluctuations have long run and short run impact on manufacturing sector output. The study further revealed a positive but insignificant impact of exchange rate fluctuations on manufacturing sector output. The author recommended that government should put policies in place that can boost exports and reduce imports so as to achieve a favourable balance of payment. It was also recommended that the government should encourage the use of local materials in production so as to promote international competitiveness and equally increase expenditures on economic services such as manufacturing in order to increase their output

\section{METHODS}

\section{Model specification}

The study aimed to specify empirical model in order to examine the impact exchange rate volatility on manufacturing sectors in sub-Saharan Africa. The log-linear equation for exchange rate volatility is hereby specified as;

$$
\begin{aligned}
& \operatorname{lnMAN}_{i t}=\beta_{0}+\beta_{1} \ln R E X C R_{i t}+\beta_{2} \ln G D P_{i t}+\beta_{3} \ln R I N T_{i t}+\beta_{4} T O P_{i t}+ \\
& \beta_{5} \ln H U M_{i t}+\beta_{6} \operatorname{lnINF_{it}}+\varepsilon_{i t}
\end{aligned}
$$

\section{Data sources and variable measurements}

All the Data for this study were obtained from World Bank Development Indicator (WDI). The countries included in this study are, Cameroun, Central Africa Republic, Cote d'ivore, Ghana, Lesotho, Malawi, Nigeria, Sierra Leone, South Africa, Togo and Uganda. 
Manufacturing sector (MAN) is measured by manufacturing value added ( $\%$ of GDP); Exchange rate volatility (ECXV) - Exchange rate volatility is a measure that will be used to capture the uncertainty faced by manufacturer sector due to erratic fluctuations in the exchange rates. Due to the unobservable nature of this variable its measure has been generating controversy in the literature. This study therefore, follows recent literature and uses the measures derived from the GARCH $(1,1)$ model as measures of exchange rate volatility. Following Yinusa (2005), the conditional volatility of exchange rate was extracted and model through a state space representation of the form:

$$
\begin{aligned}
& Z_{t}=\delta \varepsilon_{t} e^{\frac{1}{2 h t}}, \varepsilon_{t} \\
& h_{t+1}=\pi h_{t}+\mu_{t}, \quad N I D\left(D, \delta^{2} \mu\right) / \pi / \leq 1
\end{aligned}
$$

$Z_{t}$ is the exchange rate, $\delta^{2}$ is a scale factor and subsumes the effect of a constant in the regression of $h_{t}, \pi$, is a parameter, $\mu_{t}$ is a disturbance term that is uncorrelated with $\varepsilon_{t}$ is an iid $(0,1)$ are random disturbances symmetrically distributed about zero. The $h_{t}$ equation is a transition equation in autoregressive form where the absolute value of $\pi$ is less than unity to ensure that the process in Equation (2) is stationary (3). These equations generate the conditional volatility of exchange rate. Gross Domestic Product (GDP): This is the productive capacity of an economy. Real Interest Rate (RINT) is measured by Real interest rate

Physical capital is proxied by gross capital formation (\% GDP). Trade Openness (TOP) is measured as the sum of import and export as a percentage of GDP. Inflation is the consumer prices (annual \%).

\section{EMPIRICAL RESULTS}

The analysis of this study started by performing a panel unit root test so as to deal with the problem of heterogeneity biases that are common characteristics of panel data analysis. Specifically, this study used Levin, Lin \& Chu, Im, Pesaran and Shin, ADF-Fisher Chi-square and PP-Fisher Chi-square tests. All these tests assume individual unit root process to allow for heterogeneity across cross-sectional units. The results of the panel unit root tests are presented in table 2.

\begin{tabular}{|c|c|c|c|c|c|c|c|c|c|}
\hline Variable & Level & LLC & p-v & IPSS & p-v & ADF & p-v & PP & p-v \\
\hline \multirow[t]{2}{*}{$\operatorname{lnMan}$} & 0 & 0.29 & 0.61 & 0.19 & 0.57 & $34.46 * *$ & 0.04 & 20.08 & 0.57 \\
\hline & 1 & $-0.65^{*}$ & 0.00 & $-9.81 *$ & 0.00 & $133.7 *$ & 0.00 & $233.9 *$ & 0.00 \\
\hline \multirow[t]{2}{*}{$\operatorname{lnGdp}$} & 0 & 2.11 & 0.98 & 2.55 & 0.99 & 18.97 & 0.64 & 16.06 & 0.81 \\
\hline & 1 & $-5.27 *$ & 0.00 & $-6.94 *$ & 0.00 & $91.49 *$ & 0.00 & $59.87 *$ & 0.00 \\
\hline \multirow[t]{2}{*}{ lnOpen } & 0 & $-1.7 * *$ & 0.03 & $-1.7 * *$ & 0.03 & 37.84 & 0.08 & 40.88 & 0.00 \\
\hline & 1 & $-10.0^{*}$ & 0.00 & $-11.8 *$ & 0.00 & $165.79 *$ & 0.00 & $253.9 *$ & 0.00 \\
\hline \multirow[t]{2}{*}{ lnphy } & 0 & $-5.81 *$ & 0.00 & $-5.71 *$ & 0.00 & $79.75^{*}$ & 0.00 & $58.88^{*}$ & 0.00 \\
\hline & 1 & $10.05^{*}$ & 0.00 & $12.89 *$ & 0.00 & $182.54 *$ & 0.00 & $105.22 *$ & 0.00 \\
\hline \multirow[t]{2}{*}{$\operatorname{lnInt}$} & 0 & -0.30 & 0.37 & $-3.83^{*}$ & 0.00 & $62.88 *$ & 0.00 & $112.53 *$ & 0.00 \\
\hline & 1 & $-8.28^{*}$ & 0.00 & $-15.9 *$ & 0.00 & $230.77 *$ & 0.00 & $268.92 *$ & 0.00 \\
\hline \multirow[t]{2}{*}{ lnExcrv } & 0 & $-2.22 *$ & 0.00 & $-10.2 *$ & 0.00 & $140.89 *$ & 0.00 & $293.75^{*}$ & 0.00 \\
\hline & 1 & $-4.28 *$ & 0.00 & $-3.88^{*}$ & 0.00 & $55.23^{*}$ & 0.00 & $70.144 *$ & 0,00 \\
\hline \multirow[t]{2}{*}{$\operatorname{lnInf}$} & 0 & $-3.19 *$ & 0.00 & $-3.88 *$ & 0.00 & $55.23^{*}$ & 0.00 & $70.14 *$ & 0.00 \\
\hline & 1 & $-9.40^{*}$ & 0.00 & $-13.6^{*}$ & 0.00 & $197.75^{*}$ & 0.00 & $314.19 *$ & 0.00 \\
\hline
\end{tabular}

Table 2. Panel unit root tests-individual effects

Notes: The null hypothesis (Ho) is that there is unit root, (H1) some do not have a unit process. Significance levels are denoted by *: $1 \%$, **: 5\%, ***: 10\%: and indicate rejection of the null hypothesis. 0 and 1 represent level and first difference respectively. Probabilities for Fisher tests are computed using an asymptotic Chi-square distribution. All other tests assume asymptotic normality. LLC represents Levin, Lin and Chin, IPS represents Im Pesaran Shin, ADF indicates Augmented Dickey Fuller test, PP denotes Phillip Peron, Hadri Z Stat is also reported, and P-V indicates Probability Value. 
The results of the panel unit root tests show that some variables are stationary at levels while others are stationary at first difference. Physical capital, exchange rate volatility and inflation are stationary at levels while manufacturing, gross domestic product, trade openness and interest rate are stationary at first difference.

Based on the properties of the unit root tests, the attention now focused on the estimation of pooled OLS, fixed effect and system Generalised Method of Moment (GMM). The results of the pooled OLS, fixed effect and dynamic GMM are presented in table 3 below. The pooled OLS results is in column 1, fixed effect results in column 2 and the system GMM is presented in column 3.

Table 3. The results of panel data estimates

\begin{tabular}{|c|c|c|c|}
\hline Variables & Pooled OLS & Fixed Effect & System GMM \\
\hline $\mathrm{C}$ & $\begin{array}{r}0.5694 \\
(1.4891)\end{array}$ & $\begin{array}{c}4.2639 * \\
(7.3878)\end{array}$ & - \\
\hline$M A N_{i t}$ & & & $\begin{array}{c}-0.0410^{*} \\
(-2.7899)\end{array}$ \\
\hline $\operatorname{lnGdp}$ & $\begin{array}{l}0.2017 * \\
(6.4474)\end{array}$ & $\begin{array}{r}-0.1958 * * \\
(-2.2132)\end{array}$ & $\begin{array}{r}0.0091 \\
(1.0540)\end{array}$ \\
\hline lnOpen & $\begin{array}{r}-0.0516 \\
(-0.8356)\end{array}$ & $\begin{array}{c}-0.2233^{*} \\
(-3.8408)\end{array}$ & $\begin{array}{r}-1.1230 \\
(-1.6610)\end{array}$ \\
\hline lnphy & $\begin{array}{c}0.3561^{*} \\
(6.1840)\end{array}$ & $\begin{array}{c}0.1810 * \\
(4.2075)\end{array}$ & $\begin{array}{c}0.0579 * \\
(3.4790)\end{array}$ \\
\hline $\ln I n t$ & $\begin{array}{r}-0.0330 \\
(-1.3142)\end{array}$ & $\begin{array}{r}-0.0035 \\
(-0.1938)\end{array}$ & $\begin{array}{r}0.0126 \\
(1.3080)\end{array}$ \\
\hline Excrv & $\begin{array}{c}-0.0293^{*} \\
(-1.8295)\end{array}$ & $\begin{array}{l}-0.0265^{*} \\
(-2.6572)\end{array}$ & $\begin{array}{r}-0.0101 * * \\
(-2.0317)\end{array}$ \\
\hline $\ln \operatorname{lnf}$ & $\begin{array}{r}-0.0539 * * \\
(-2.4422)\end{array}$ & $\begin{array}{r}0.0234 \\
(1.4430)\end{array}$ & $\begin{array}{r}0.0046 \\
(0.7559)\end{array}$ \\
\hline R-Squared & 0.29 & 0.76 & - \\
\hline Adjusted $R^{2}$ & 0.28 & 0.75 & - \\
\hline F- Statistics & 23.284 & 67.26 & - \\
\hline Durbin-Watson & 0.12 & 0.23 & - \\
\hline J-Statistics & - & - & 4.3 \\
\hline Instrument Rank & - & - & 8 \\
\hline Sargan & & & 0.3811 \\
\hline Observation & 343 & 343 & 333 \\
\hline
\end{tabular}

The pooled OLS results performed very well, the adjusted R-square is 0.28 . The F-statistics is significant. The results also show that GDP is positive and significant at 10 per cent. This implying that Gross Domestic Product (GDP) has significant positive impact on manufacturing sector. The trade openness and interest rates are negative but they are statistically insignificant. The coefficient of physical capital is positive and significant at 1 per cent. The exchange rate volatility negatively impacted manufacturing sector as its coefficient is negative and significant at 10 per cent. The coefficient of inflation is negative and significant at 5 per cent. This is implying that inflation has negative impact on manufacturing sector. 
The fixed effect results in column 2 show that Gross Domestic Products (GDP) and trade openness have negatively impacted manufacturing sector and they are statistically significant at 1 per cent and 5 per cent respectively. Physical capital is positive and significantly impacted manufacturing sector at 1 per cent. The coefficient of interest rate shows a negative sign but insignificant. The exchange rate volatility result is not different from the pooled OLS result in column 1 as it is positive and significant at 1 per cent. The inflation is positive but not significant.

The system GMM in column 3 of table 3 which serves as robust check on pooled OLS and fixed effect results show that lagged manufacturing sector has negative and significant impact on current manufacturing sector. The coefficients of Gross Domestic Products (GDP) and physical capital are both positive. However, only physical capital is statistically significant at 1 per cent while gross domestic product is not significant. Trade openness remain negative as in both pooled and fixed effect results but not significant. This is consistent with Ojeyinka and Adegboye (2017) as they also found a negative relationship between trade liberalisation and manufacturing output. The exchange rate volatility is negative and statistically significant. This is consistent with Sani, Hassan and Azam (2016). Inflation positively impacted manufacturing sector but not significant. This is line with Onakoya, Fasonya and Babalola (2012) and Ojeyinka and Adegboye (2017) who found negative relationship between inflation and manufacturing sector.

The negative impact of trade openness on manufacturing sector is not surprising as trade openness open doors for the importation of varieties of manufactured products from developed countries which leads to the low demand for the local manufactured products. The superior quality of imported manufactured products make it more desirable and preferable to local manufactured products in sub-Saharan Africa and this has negatively impacted the manufacturing industries. The coefficients of interest rates are not statistically significant in any of the estimations therefore conclusions can not be drawn. However, Raufu, Morgan and Alan (2018) found in their study a negative relationship between interest rate and industrial output in sub-Saharan African. The positive and significant impact of physical capital on manufacturing sector is an indication that physical capital contributes to manufacturing development of subSaharan Africa. The availability of basic infrastructure such as good roads, electricity and other facilities could lead to the increase in output of manufacturing sector. For instance, the availability of constant and regular power supply will reduce the cost of production of the manufacturing sector. The reduction of cost of production enables the industries to lower the price of their products and as a result the demand for their product will increase.

The negative and significant impact of exchange rate volatility on manufacturing sector shows that manufacturing sector is unable to cope with volatility of exchange rate in sub-Saharan Africa. The negative impact of the exchange rate volatility could be traced to two links in sub-Saharan Africa. The first link has to do with raw materials of the manufacturing industries. Most of the manufacturing industries in sub-Saharan Africa depend on imported raw materials and the volatility of the exchange rate affect the prices of the imported raw materials. In case of depreciation of currency, the prices of raw materials will be very high and this will affect the volume of raw materials demanded by the manufacturing industries which in turn reduced their output. Though the depreciation of currencies in sub-Saharan Africa should lead to increase in exportation of manufacturing products because depreciation makes the manufactured products exported to be cheaper but the demand for Africa manufacted products in 
developed countries is very low. The second link has to do with the output of the manufacturing sector. The volatility of exchange rate has direct impact on the output of the manufacturing sector. The appreciation of currency in sub-Saharan Africa makes imported manufactured products cheaper which reduces the demand for the local manufacturing products while on the other hand the appreciation of local currency makes the prices of the exported products high and this will lead to decrease in demand for the exported goods.

\section{CONCLUSION AND RECOMMENDATIONS}

\section{Conclusion}

This study empirically examined how volatility of exchange rate impacted manufacturing sector in sub-Saharan Africa. The results of various studies on the relationship between exchange rate volatility and manufacturing sector have produced mixed results in the literatures. The results of this study indicated that volatility of exchange rate has significant negative impact on manufacturing sector in sub-Saharan Africa during the study period.

\section{Recommendations}

Based on the inverse relationship found between exchange rate volatility and manufacturing in this study, it is recommended that the government of sub-Saharan African countries must take the necessary steps and policies to reduce importation particularly the raw materials use by the industries in the region. Since it has been discovered the exchange rate volatility have greater effect on the manufacturing and the economy at large when the importation is high. In addition, all the goods that are being imported but they can be produced locally must be reduced. This will expand the market for the locally produce goods and prevent them from unnecessary competition with imported goods and hence reduced the impact of exchange rate volatility. The government must also provide conducive environment for the smooth operation of the manufacturing sector. Regular electricity supply, good roads, water supply and other infrastructure facilities that will enable the industries to operate at the minimum cost must be provided as all these will lead to increase in output.

\section{REFERENCES}

Abdul-Mumuni, A. (2016) Exchange Rate Variability and Manufacturing Sector Performance in Ghana: Evidence from Cointegration Analysis. International Economics and Business ISSN 2377-2301, Vol. 2, No. 1

Danmola, R. A. (2013) The Impact of Exchange Rate Volatility on the Macro Economic Variables in Nigeria. European Scientific Journal March 2013 edition vol.9, No.7 ISSN: $1857-7881$

Fakiyesi, O, \& Akan, O (2005) "Issues in Money, Finance and Economic Management" University Press Lagos.

Institutes of Developing Economies (2004) International competiveness of Manufacturing Firms in sub-Saharan Africa. Discussion Paper No 2.

Ojeyinka, T. A and Adegboye A. A (2017) Trade Liberalization and Economic Performance in Nigeria: Evidence from Agricultural and Manufacturing sectors. African Journal of Economic Review, Volume V, Issue III.

Oladipupo, A.O, and Onotaniyohuwo, F.O. (2011) "Impact of exchange rate on balance of payment in Nigeria" African research review: An international multidisciplinary Journal, Ethiopia 5(4): 73 - 88. www.Afrrevjo.Com. 
Olayungbo, D., Yinusa, O, and Akinlo, A. (2011) Effects of Exchange Rate Volatility on Trade in Some Selected Sub-Saharan African Countries doi:10.4236/me.2011.24059 Published Online September 2011 (http://www.SciRP.org/journal/me)

Omojimite, U. B, and Akpokodje, G. (2010) A Comparative Analysis of the Effect of Exchange Rate Volatility on Exports in the CFA and Non-CFA Countries of Africa 24(1): 23-31.

Omotola, L. W. (2016) Effect of Exchange Rate Fluctuations on Manufacturing Sector Output in Nigeria. Journal of Research in Business and Management Vol4(10) Pp: $32-39$

Onakoya, A. B., Fasanya , I. O and Babalola, M. T. (2012). Trade Openness and Manufacturing Sector Growth: An Empirical Analysis for Nigeria. Mediterranean Journal of Social Sciences Vol. 3 (11). Doi 10.59011/mjss. 2012.v3n11p637

Opaluwa, D., Umeh, J. C, \& Abu A. A. (2010). African Journal of Business Management Vol.4(14), pp. 2994-2998, 18. Available online at http://www.academicjournals.org/AJBM

Raufu, O. S, Morgan, C and Alan H, (2018). The determinants of manufacturing sector growth in Sub-Saharan African countries. Research in Business and Economics Journal Volume 12.

Sani, I. A., Hassan, S, and Azam, M. (2016) Effects of Exchange Rate Volatility on Outputs in some selected West Africa Countries. International Journal of Development and Economic Sustainability Vol.4, No.1, pp.1-10.

Sekkat, K and Varoudakis, A (2002) The Impact of Trade and Exchange-Rate Policy Reforms on North African Manufactured Exports. Development Policy Review, Vol. 20, pp. 177-189, Available at SSRN: https://ssrn.com/abstract=312191

United Nations Development Organization (2014), Industrialization, Environment and the Millennium Development Goals in Sub-Saharan Africa. Industrial Development Report 2014. Vienna

UNIDO (2016), The Role of Technology and Innovation in Inclusive and Sustainable Industrial Development. Industrial Development Report.

Yinusa, D. O. (2005) "Exchange Rate Variability, Currency Substitution and Monetary Policy in Nigeria (1986-2001)," An Unpublished Ph.D. Thesis, Depart Economics, Obafemi Awolowo University, Ile-Ife, Nigeria. 